\title{
A Tentative Application of Teaching English Songs in English Phonetics Course
}

\author{
Yu Zhang \\ Foreign Language Department \\ The Engineering and Technical College of Chengdu University of Technology \\ Leshan, China
}

\begin{abstract}
The present state of English phonetics teaching in China has a lot of problems, although the importance of speech has been more and more widely recognized, however, teachers themselves have their own difficulties, for most of them are not native English speakers, their pronunciations are not so authentic and pure. Therefore, for teachers who engage in English phonetics teaching, it's an obligation for them to settle an appropriate method and find suitable ways in teaching students' English phonetics, such as utilizing English songs as a teaching media for students to learn. On review of the current English phonetics teaching and considering the features of English songs, while by discussing on the connections and previous research achievements between English songs and English phonetics teaching, and by presenting an instance analysis in teaching English Pronunciation and Intonation Course for freshmen of English majors, this essay is devoted to make a brief analysis on the application of teaching English phonetics by means of English songs, with the case study and analyses indicate that the integration of learning to sing English songs and English phonetics teaching could stimulate students' interests, make teachers and students get closer, change the status quo of teacher-oriented teaching into students' self-directed learning, and finally, the mission of improving students' language competences and developing students' independent learning ability are completed.
\end{abstract}

Keywords-English Phonetic Teaching; English Songs; Language Competence; Self-directed Learning

\section{INTRODUCTION}

The famous linguist A. C. Gimson [1] said: "to speak any language a person must know nearly $100 \%$ of its phonetics, while only $50 \%-90 \%$ of its grammar and $1 \%$ of the vocabulary may be sufficient." Language is the most important communication tool for human being. Its function though voice, which represents certain significance to reflect. People get to know others' thoughts and feelings through language.

However, the essence of language is speech, which is the material base of language that is to say, language can't exist without speech. In terms of language learning, whether professional or non-professional, learning for a long time or short time, no matter for the sake of the future reading or interpretation, pronunciation can't be omitted or ignore. Obviously, to learn a language well, phonetics is a key point.
As a renowned thinker, philosopher and writer, Rousseau believed that language and music come from one source, and he detailed in the article On the Origin of Language [2] and systematically expounds the view that language originated in the ability of singing of human, the interpersonal communication has a natural cadence, and the tone and rhythm that come from people's excitement, agitation or sadness, is song.

Considering the factors above, the author of this paper combines English songs and phonetics teaching and learning together, hopefully to find an interesting method in English phonetics teaching.

\section{LITERATURE REVIEW}

In this chapter, a review of phonetics teaching and a brief features of English songs are presented, which will lay a solid theoretical foundation for the following discussion.

\section{A. The Review of Phonetic Teaching}

In the Middle Ages: it makes sure that as long as language teaching appears, pronunciation teaching is of course a part of it. However, pronunciation teaching was not an important role in early English teaching. At that time, people usually focused on written forms, and oral practice was not important in their mind.

At the end of $19^{\text {th }}$ century: thanks to the good opportunity that brought by the Reform Movement (famous for the absolute priority of speaking in English teaching), which made people have a new understanding of language-language at first is vocal in social communication [3]. Thus language teaching should not be limited to written forms, but should lay more stress on oral communication.

Before $20^{\text {th }}$ century: own to the inadequate attention on pronunciation, some pronunciation was not standard. English teachers realized that English reform should begin with correct phonetics transcription, and to keep English pronunciation standard, they need good pronunciation training, and at the very time, with the Reform Movement, Henry Sweet, Wilhelm Vietor and Paul Passy established IPA (International Phonetics Association) and defined international phonetic symbols. 
Early language teaching mainly depends on teachers' introduction and students' imitation. The changing happened at nearly $20^{\text {th }}$ century.

At the beginning of $20^{\text {th }}$ century: in 1987, M. Celce pointed out that "the Direct Method" [4] (instead of stressing on translation, form, grammar and learners' mother tone, adopting foreign language to teach foreign language) has claimed that pronunciation is very important and presents it via teachers' modeling. According to phonetic study, language teachers decide which vowels and consonants should be taught first, and what come afterwards. Under the influence of "Direct Method", intuitive-imitativerepetitive approach appeared.

In 1940s and 1950s, influenced by the emergence of Structural Linguistics (which emphasizes the relations of language with its surrounding and the facts which history, social sciences or cultural science could offer for the understanding of language), Audio-lingual and Oral Approach became popular [5]. Those methods further enhanced the pronunciation teaching. At that time, pronunciation teaching began to use phonetic symbols, and speech organ pictures to conduct more effective pronunciation teaching, which emphasized more on the exercise of sentence structures and the development of learners' pronunciation habit.

Modern language teaching began important at the end. Apart from the teachers' modeling, students' repeat, and teachers often design phonetic comparison drills mode, which has been used for many years and played an important role in the English pronunciation teaching.

From 1970s, Communicative Approach [6] emerged, which claimed the first purpose of the language was communication. And at that time, people gradually recognized the ultimate purpose of pronunciation teaching was not to make learners reach the level of native speakers but to make the communication understood. Under the influence of Communicative Approach, training methods of pronunciation varied. Here are some aspects:

- Listen and imitate;

- Phonetic training;

- Minimal pair drills;

- Visual aids;

- Tongue twisters;

- Reading aloud/recitation;

- Recordings of learners' production.

\section{B. The Features of English Songs}

In the 1950s-Rock and Roll: came out of the chaos all around the world after WWII, and became all the rage in the 1960s. At that time, western world has experienced a big oscillation; the young generation showed unprecedented rebellious spirit and wanted to against the society, against parents and all the traditional things. They were to break all the shackles, all the rules and all existing things.
In the 1970s: own to the Vietnam War, many youth lost their lives for this ridiculous war. People become more confused and opposite to the government, and no longer believe their country could bring them harmony. And that's why the English songs then paid more attention to social problems, rather than the pure spiritual revolution in 1960s.

In the late 1970s, early 1980s: a time of Heavy Metal. There are various famous band and album in the 1980s, which warmed countless lonely, extreme, angry youth, and gave them new faith and hopes.

After the 1980s: various types of the non-mainstream, such as Electronic Music, which has sent a challenge to the heavy metal, which gradually lost its dominance.

In the 1990s: a leaderless period. Needless to say, there are some high lights, such as Punk, which characterized itself of a self-deprecating mixture of hope and despair, confidence and inferiority that comes out of the death of their hope.

\section{The PREVIOUS RESEARCH ON TEACHING SONGS IN PHONETICS}

According to author's observation and teaching experience, whether learners are interests in English will affect their exams a lot. So this chapter aims to draw learners' attention through the first research, cultivate their interest via the second research, and deepen their knowledge in songs and phonetics learning through the third research.

\section{A. The Matchless Memory}

The famous psychologist and educator George Lozanov started a research on "why some people have extraordinary memory?" in the 1950s. After years of research, he concluded that each of us has a best state for learning, which occurs only when the heartbeat, breathing rate and brain wave come to the synchronization [7].

At this time, the body is relaxed, while mind focuses and ready to receive new information. Furthermore, he put the research into practice and obtained gratifying achievements, especially in foreign languages' learning. Based on psychology and Medicine, he developed a new learning method-60 pat music per minute method that raised in Baroque period. Tests showed that people's memory could increase by more than $15 \%$ when the slow music is played during their learning. One of his famous experiments is in a class, in which he taught 15 lessons, covers 500 words, the tests after the class and the one three days after turned out to be a success. In the early $60 \mathrm{~s}$, the most famous language training school, Berlitz, promised that the students could memorize 200 words in a couple of days (about 30 hours), while Lozanov's research report indicates that the students in Bulgaria could learn 1200 words a day.

\section{B. Jazz Chants}

Jazz Chants started in the 1970s, when the listen and imitate was still in its day. Even today, the Jazz Chants is still can be heard in the ESL (English as a second language) and EFL (English as a foreign language). The founder of Jazz Chants, Carolyn Graham [8], who is an English 
professor in New York University, analyzed the features of Jazz Chants as followed:

- Jazz Chants characteristics itself with natural rhythm. After years' observation and practice, she found that American English rhythm and traditional American Jazz rhythm are striking similar. Under this situation, she started her research and practiced it in the University of New York. The results showed a better teaching effect, students' pronunciation has a great progress, especially in rhythm and language adjustable aspects. It's obvious that Jazz Chants with the dialogue strong rhythm is greatly promoted the speech and language learning.

- Jazz Chants combines phonetics teaching and meaningful communication activities. Jazz Chants maintains the characteristics of the traditional practice of sentence patterns, such as words and patterns of repetition, etc., and contains meaningful interesting communicative dialogue. The words or sentences in it are real and practical.

- It is interactive. Although this teaching mode contains a large amount of repetition, the situation happens in only two or a few people. Jazz Chants often begins with listening and practicing, and ends up with role play.

- It notices on students' emotional factors, and can not only reduce the worries and depression on learning a foreign language, stimulate their learning motivation and interest, but also can mobilize those many kinds of senses to learn. Students can read, communicate with each other, recite, sing, beat and do body exercises to the chant. Also, it makes students get excited about learning English. Graham noted, recite dialogue and singing alone is not the purpose of learning, the more important thing is to learn through dialogue and sing to create their own dialogue, short poem, telling a story, create a relaxed and fun learning environment at the same time, so that they will be happy to learn and use English.

\section{Rhythm Explore}

The rhythm of the music refers to the combination of the length of the sound and regular weak relations.

The rhythm of the language means the combination of priorities, high and low change and pause and intermittent of language, which appears alternately.

Different language has different rhythm. The rhythm of English phonetics features and characteristics and the rhythm of music have shocking similarities. A good grasp of the rhythm of the music, will be a significantly help for English speech learning. The commonness is mainly manifested in the following aspects:

- The interval and strong contrast of light and stress. In the music, the length of the same or different sound are organized according to the certain rules; the downbeat and upbeat's periodically and regularly recurring form the beat. Measure unit is a fixed note, called beat. Such as, a music of $2 / 4$ pat means a quarter note to be one pat, every section contains strong and weak two pats. As for the music melody, stress is the rhythm, which plays a basic role for melody's vividly playing [9]. English is accent rhythm language (stress-timed language); generally speaking, there is more than one syllable in a word or a sentence. Some syllables need stress, while others don't. Those stressed and unstressed intervals form beat. English sentences are composed of rhythm groups, which contain stressed syllable and the one or ones that following syllable is the smallest unit of English rhythm. Each group, no matter how many the syllables are in a rhythm, there is only one syllable stress, which plays a central role in terms of English rhythm and this feature, is similar to the rhythm of music.

- The time between the beat is equal. According to the needs of rhythm and melody, there will be a variety of duration of music notes, to record the sound's length [10]. The most common music notes are whole note, half note, quarter note, quaver, and so on. Generally, a quarter notes to be one pat and the pats for each part are the same. Take $2 / 4$ music as an example, there are two pats for each section; 3/4 music means every section has three pats, etc. Therefore, the more music notes within one section, the less duration time for each. The relationships are: a semibreve is equal to two half notes; a half note equals two quarter notes, and so on. English is an accent meter timing language, measured by the stress and syllable. Always, the core of English sentence is stress, and the branch is light, and their alternately appearing keeps equal time between stresses. In order to obtain the result of this time interval, people take various actions to adjust during their talking and reading. Such as a slow speech when light tone is less, a quick talking when light tone is more. Take Carly Rae Jepsen's [11] song as an example:

Hey I just met you / and this is crazy

[heI][aI] [djast] [met] [ju:] / [aend] [ðIs] [Iz] ['kreIzI]

But here's my number / So Call Me Maybe

['merbI]

[bıt] [hı'z] [maI] ['nımba] / [sau] [ks:l] [mI]

This song is a note of 4/4, even the words aren't the same number, and the time that each section used is the same.

\section{THE TEACHING STEPS}

The preceding content gives theoretical concepts. The following chapter will deal with the operating steps, which are connected with the concepts, so that the paper could be a practical assistant in English study. The author has taught English Pronunciation and Intonation Course for freshmen of English majors for many years, the procedure of teaching can be divided as before the class, during the class and after the class, in each section, the teacher would inform students 
their task in learning English phonetics by singing English songs.

\section{A. Before the Class \\ Step1: Interest inventory}

As the author of this paper mentioned at the beginning, interest is a strong motivation on learning, which oils the progress of learning and ease one's pressure. In order to make students more willing to learn and accept, teachers need to ask their interest on music, for some like rock, while others prefer countryside style.

\section{Step 2: Choosing the songs}

There're many methods when learning one kind of knowledge, summarizing and contrast, for instance. Here, when choosing the song, a key question should be considered: whether the song covers the factors that are talked about here. The answer to it is positive. The songs one chose must have relevance to the knowledge, both the relevance and contrast work [12].

\section{B. During the Class}

\section{Step 3: An exciting beginning}

At the beginning of the class, many students are not on the earth yet. My suggestion is to play the song first, and draw their attention to the song that teacher is playing. Fluently, lead students to the knowledge that today will be learned.

\section{Step 4: Detail theoretical knowledge}

After the attention-drawing, teachers need to strike while the iron is hot, and extend the knowledge in the lyrics to the textbook. To some extent, this step is a reviewing of the Step 3 , which creates students a more firmly memorizing.

\section{Step 5: Combining}

When the class goes to this step, the instructor only need to click the play key and the class is over. In fact, it means a combination of learning and interests, and that makes one's learning easier and happier. People always prefer an easier and shorter way; after all, sluggishness is human being.

\section{After the Class}

\section{Step 6: Reviewing}

This step is the easiest part. The only thing that supervisors need to do is to tell them one saying: All work and no play makes Jack a dull boy, vice versa, and the page can be turned.

\section{INSTANCE ANALYSIS}

In this chapter some instance analyses are listed to show how to apply English songs in teaching students' English phonetics in vowels, consonants and linking.

\section{A. Vowels}

The vowels here are to help the beginners to practice and memorize vowels more efficiently and easily. Vowels are sounds in which there is no obstruction to the flow of air as it passes from the larynx to the lips. There are 20 vowels in
English, among which 12 are pure vowels and 8 are diphthongs. Generally, there're three kinds of classification for pure vowels: according to the height of the raised part of the tongue, the part of the tongue is raised and the position of the lips and the following are the examples of the second classification [13].

1) Front vowels: / : :/ / / / /e/ /æ/

Pronunciation skills: the tongue tip is close to the inferior alveolar, the front of the tongue is up to the palate, without contact, and the position of tongue is from high to low $/ / \mathrm{I}: />$ $/ \mathrm{I} />/ \mathrm{e} />/ \Re /$ ), the opening degree of mouth is from small to

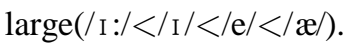

Example song:

\section{My Heart Will Go On—Celine Dion}

Every night in my dreams,

['evrI] [In] [drI:mz]

I see you Ifeel you, that is how ...

[s $I:] \quad\left[f_{I}: l\right] \quad$ [ðat $][I z]$

2) Central vowels: /ə://ə/

Pronunciation skills: the middle of the tongue is up to the palate, and the position of $/ \mathrm{a}$ //is higher than that of $/ \mathrm{\partial} /$, and the lip is shaped oblate.

Example song 1:

Holiday_Hilary Duff

I remember summers you and me lasting forever [rI'memba]['sıməz] [fa'reva]

Holidays come we'd never never ever be apart.

Example song 2: ['neva] ['eva] [a'pa:t]

Nobody's Perfect-Miley Cyrus

Nobody's perfect! I gotta work it. ['po:fikt] [wo:k]

Nobody's perfect! You live and learn it! ['po:fikt] [lo:n]

3) Back vowels: /u:/ /u/ /o:/ /o/ / / /a:/

Pronunciation skills: the back of the tongue is up to the palate without touch, and the height of tongue is like $/ \mathrm{u}: />/ \mathrm{u} /$ $>/ \mathrm{o} / />/ \mathrm{\rho} />/ \Lambda />/ \mathrm{a}: /$.

Example song:

God Is A Girl_Groove Coverage

Remembering me discover and see [dI'skıva]

All over the world she's known as a girl

[o:l]

To those who are free the mind shall be key

[tu] [hu:] [a:]

Forgotten as the past cause history will last

$$
\text { [azz] [pa:st] [ko:z] [la:st] }
$$

God is a girl wherever you are

[god] [ju:]

do you believe it can you receive 


\section{[du:] [kan]}

4) The diphthongs: /e I/ /a I / / I / /au/ /au/ / гa/ / عə//uə/

Pronunciation skills: the sliding from the first note to the second one.

Example song:

Pretty Boy-M2M

I lie awake at night see things in black and white

[a I][la I][a'we Ik] [na It] [waIt]

I've only got inside my mind

[av]['Junl I][ In'sa Id][ma I][ma Ind]

you know you have made me blind

[nau] [me Id] [bla Ind]

I lie awake and pray that you will look my way

[a I] [la I][a'we Ik] [pra I] [we I]

I have all this longing in my heart

[a I] [maI]

I knew it right from the start

[aI] [ra It]

Oh my pretty pretty boy I love you

[əu] [maI] [bоI][aI]

like I never ever loved no one...

[laIk][aI] [nau]

\section{B. Consonants}

Classifications: generally, consonants can be simply divided into two parts: the voiceless $(/ \mathrm{p} / / \mathrm{t} / / \mathrm{k} / / \mathrm{f} / / \mathrm{s} / / \mathrm{S} / / \mathrm{e} / / \mathrm{f} /$ $/ \mathrm{h} /$ ), which means a non-vibration on vocal cords, and voiced (/b//d/ /g//v//z/ /3//ð//d $/ / \mathrm{r} / / \mathrm{m} / / \mathrm{n} / / \mathrm{g} / / \mathrm{l} / / \mathrm{w} / / \mathrm{j} /)$ which means the vibration on vocal cords. Besides, there is a more complicated classification for consonants as follows.

1) The plosive consonants (stops): /p//b//t/ /d/ / / / g/.

Pronunciation skills: they are made by completely stopping the airflow at some point in the mouth and then, for most productions, releasing it into the sound that follows. $/ \mathrm{p} /$ and $/ \mathrm{b} /$ are formed by the lips, $/ \mathrm{t} /$ and $/ \mathrm{d} /$ are made on the gun ridge behind the upper teeth, while $/ \mathrm{k} /$ and $/ \mathrm{g} /$ occur at the back of the mouth where the tongue makes a weal with the soft palate. The plosive consonants sometimes would loss of plosion [14], such as:

- The plosive consonants + the plosive consonants: instead the first plosive consonant, the second one does the plosion, while the first one just keep the pronunciation posture, e.g. suitcase.

- The plosive consonants + the affricates: the plosive consonant just keep the posture, and one should skip to the affricate, e.g. picture.

- The plosive consonants + the fricative consonants: the plosive consonant just keep the posture, the fricative consonant should do the pronunciation, e.g. keep silent.

- The plosive consonants + the nasals $(/ \mathrm{m} /, / \mathrm{n} /)$ : the plosive consonants just keep the posture, e.g. a mad man.
- $\quad$ The plosive consonants + the lateral (/l/): it follows the principles above, e. g. good luck.

Example song:

Need You Now_L L Lady Antebellum

Picture perfect memories scattered all around the floor.

Reaching for the phone cause I can't fight it anymore.

And I wonder if I ever cross your mind.

For me it happens all the time.

It's a quarter after one I'm all alone and I need you now.

Said I wouldn't call but I lost all control and I need you now.

And I don'ț know how I can do it without I just need you now.

Except for the loss of plosion, there is an interesting phenomenon for $/ \mathrm{p} / / \mathrm{t} / / \mathrm{k} /$ that called the voicing of the voiceless consonants when they followed with /s/:

$$
\begin{array}{ll}
\text { - } & / \mathrm{s} /+/ \mathrm{p} / \rightarrow / \mathrm{b} / \text { e.g. sport, speak } \\
\text { - } & / \mathrm{s} /+/ \mathrm{t} / \rightarrow / \mathrm{d} / \text { e.g. student, } \underline{\text { sting }} \\
\text { - } & / \mathrm{s} /+/ \mathrm{k} / \rightarrow / \mathrm{g} / \text { e.g. } \underline{\mathrm{sk}} \mathrm{y}, \underline{\text { skirt }}
\end{array}
$$

Example song:

Get the Party Started_—Pink

I'm coming up so you better get this party started

I got lots of style check my gold diamond rings

License plate says Stunner Superstar.

2) The fricative consonants: /f/ /v//s//z//S//z//e//ठ//h/

Pronunciation skills: the airstream is partially blocked and caused the friction-like noise characteristic of these sounds./f/ and $/ \mathrm{v} /$ : produced by forcing the breath stream between your upper teeth and lower lip. /s/ and /z/: produced by forcing air between the tongue and the upper or lower front teeth. When nouns ends in voiceless consonant sounds, the pronunciation is $/ \mathrm{s} /$, when the nouns ends in vowel sounds or voiced consonant sounds $(/ \mathrm{b} /, / \mathrm{d} /, / \mathrm{g} /, / \mathrm{n} /, / \mathrm{r} /)$, the pronunciation is $/ \mathrm{z} /$, and when the nouns ends in "s", $/ \mathrm{t} \int /$, $/ \mathrm{S} /$, the pronunciation is $/ \mathrm{iz} / . / \mathrm{S} /$ and $/ 3 /$ : produced in much the same way as the $/ \mathrm{s} /$ and $/ \mathrm{z} /$, except the tongue is farther back and the lips are rounded. $/ \Theta /$ and $/ \delta /$ : produced by squeezing the breath stream between your tongue and teeth. /h/: simply a stream of air from the larynx directed through the open mouth.

Example song:

Road Trip—Darin

Baby I got love for you, [lav][fo:]

and I appreciate the things you do

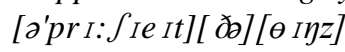

But I got no reason to stay, ['r I:z(a)n] [ste I]

cause somehow we don't seem to work it...

[ks:z] ['sımhau] [s I:m]

And baby ain't it what it's all about,

think I gotta take a break

[o I $\mathrm{Ik}$ [brek] 
Trying to figure out, where we be ending up ['f Iga]

I have to follow my intuition make a decision

[hav] ['folou] [ Intju'IS(a)n] [dI's Iz(a)n]

3) The affricative consonants: $/ \mathrm{t} / / \mathrm{d} g /$

Pronunciation skills: they are produced by blocking off the breath-stream between the tongue and gum ridge, for a stop and a fricative. As for the other four are: /ts/ /dz/ / tr/ /dr/.

Example song:

Can We Dance — The Vamps

I talk a lot of shit when I'm drinking baby

$$
\text { ['drink In] }
$$

Don't mind all my friends, I know they're all crazy [frendz]

That's all I have to say so baby can we dance

[ðats]

Stupid words keep falling from my mouth, [wa:dz]

please say she'll change.

$$
\text { [te ind } 6]
$$

4) The nasal consonants: $/ \mathrm{m} / / \mathrm{n} / / \mathrm{n} /$

Pronunciation skills: $/ \mathrm{m} /$ : occurs at the front of the mouth and is grouped with the labials. $/ \mathrm{n} /$ : is produced on the upper gum ridge and is alveolar. $/ 5]$ : made with the back of the tongue touching the soft palate.

Example song:

I Like It Like That_-Hot Chelle Rae

Let's get it on, yeah, you all can come along

$$
\text { [on] [kan][kAm][o'lon] }
$$

Everybody drinks on me, bought out the bar [drinks][on][m $\left.\mathrm{m}_{\mathrm{i}}\right]$

Just to feel like I'm a star,

$$
\text { [a Im] }
$$

now I'm thanking the academy.

[nau][a Im] [ooekg]

Missed my ride home, lost my iPhone

[m Ist] [ma I] [houm] [ma I]['a Ifoun]

5) The lateral consonant: ///

Pronunciation skills: typical produced with potential air flow around one or both sides of the tongue make it unique among English speech sounds. The key point for /1/ is the "clear-l" (e.g. lamb) and "dark-l" (e.g. turtle). Some of my classmates are still unable to distinguish $/ \mathrm{n} /$ and $/ \mathrm{l} / \mathrm{clearly}$, and the following may offers them a help on dealing with that.

Example song:

It's My Life-Bon Jovi

It's my life and it's now or never

[la If](clear-l) [nau] ['neva]

I ain't gonna live forever,

$$
\text { [l I } v](\text { clear-l) }
$$

I just want to live while I'm alive [wa Il](dark-l) [a'la Iv](clear-l)
It's my life my heart is like an open highway

[la If](clear-l) [la Ik](clear-l)

Like Frankie said I did it my way

[la Ik](clear-l)

I just wanna live while I'm alive

It's my life

$$
\text { [wa Il](dark-l)[a'la Iv](clear-l) }
$$

$$
\text { [la If](clear-l) }
$$

6) The approximants: / $/ / / \mathrm{r} / \mathrm{j} /$

Pronunciation skills: /w/ is similar to/u:/, and /j/ is very much like the vowel /г:/ and that's why they're called semivowels.

Example song:

Give Your Heart A Break—Demi Lovato

When will you realize, baby I'm not like the rest

[wen] [wil] [ju:]['r Iala Iz]

Don't wanna break your heart, ['wona]

wanna give your heart a break

['wono]

\section{Linking}

When speakers of English are speaking, they arrange words into groups and join together the stressed and unstressed words within the group. They move smoothly from one word to the next without making any sudden stops.

1) To blend or join the final consonant of one word with the initial vowel of the following word, as in "girl $\_$in a big world".

2) To link the final vowels / ə:/ and / o/ to following vowel adding the $/ \mathrm{r}$ / sound, which is called linking -r, as in "major_in", or intrusive -r as "your_arms".

3) To make smooth transitions when words are separated by more than two consonants, i. e. treats them as consonant sequences, as in "big _big_girl".

4) To make smooth transitions when then preceding word ends with a vowel and the following word begins also with a vowel sound by adding a slight $/ \mathrm{j} /$ or $/ \mathrm{w} /$, as in "yellow and nice".

5) To change the pronunciation of some final and initial consonants, as in "girl_in a big world".

6) To link some of the final consonant to the following same one, as in "leaf_falling".

Example song:

Big Big World_Emilia

I'm a big big girl_in a big big world.

It's not a big big thing if you leave me. 
But I do do feel that I too too will miss you much, miss you much

I can see the first leaf falling,

it's all yellow and nice

It's so very cold outside,

like the way I'm feeling inside

I'm a big big girl_in_abig big world.

It's not a big big thing if you leave me.

But I do do feel that I'll too too will miss you much, miss you much

Outside it's now raining,

and the tears are falling from my eyes

Why did it have to happen,

why did it all have to end

I'm a big big girl in a big big world.

It's not a big big thing if you leave me.

But I do do feel that I too too will miss you much, miss you much.

I have your arms around me oh...like fire.

\section{CONCLUSION}

This essay is devoted to a brief study on phonetics teaching and English songs, which aims to improve students' language learning ability, with the cases study of being alike.

In order to make the importance of phonetics clean and clear, Gimson's "Nearly 100\% Definition" was listed at the beginning. Generally speaking, it's a scarce shortcut in English learning, which combines the entertainment and studying, which means one can improve his personal knowledge and enjoy the music at the same time [15]. What's more, the communication in songs makes people get close and more sociable. Considering those, it's really killed more than two birds with one stone.

Due to limited resources, this essay merely scratches the surface of the phonetics study and English songs learning, leaving the comprehensiveness of this topic compromised. For example, all the vowels and consonants have not been summarized in one song, so learners need to pick each from different songs.

\section{ACKNOWLEDGMENT}

I extend my sincere gratitude to a number of people who have contributed to this essay. My first acknowledgements should go to all those authors whose books I have consulted and borrowed from, for their previous research I can finish mine. My heartfelt gratitude also goes to my students, for their dynamic participation and practice English songs in my English phonetics curricular, I can accomplish my teaching process. I am particularly indebted my former colleague Miss Zheng Ruizi for her valuable suggestions on teaching English phonetics, and her MV-teaching method arouse my interesting in teaching English songs in phonetics teaching.
Last but not least, a special note of appreciation is due to my family and friends for their support and understanding.

\section{REFERENCES}

[1] A. C. Gimson. An Introduction to the Pronunciation of English. London: Edward Arnold, 1972.

[2] Rousseau. On the Origin of Language. Trans. Hong Tao. Shanghai: Shanghai People Press, 2003.

[3] Yue Jinmen. "Review and present situation of foreign language phonetics teaching" in Foreign Language, vol. 1, 2006, pp: 16-21.

[4] M. Celce. Pronunciation Teaching. London: Cambridge University Press, 1996.

[5] Gorden, Dryden. "The learning revolution" in Manitoba Teacher, vol.1, 1995, pp: 5.

[6] Wu, Xuehua. "The role of multi-media English songs teaching in SLA" in Journal of Nanjing Institute of Industry Technology, vol. 3 , 2003, pp: 47-49.

[7] $\mathrm{Bu}$, Youhong. "The role of modern instructional technology in the teaching of English phonetics." Media in Foreign Language Instruction 91 (2003): 52-55.

[8] Liao, Ying. "English songs and teaching college English listening" in Journal of Yibin University, vol. 5, 2006, pp: 95-97.

[9] Gu, Xiaoliang. "The importance of phonology in teaching basic English in teachers college" in Science and Technology Information, vol. 5, 2008, pp: 166-328.

[10] Jiang, Hongli. "On the cultivation of English phonetic habit" in Journal of Chongqing Jiaotong University, vol. 1, 2008, pp: 124-127.

[11] Lin, Xiaoshan. Classic English Songs. Beijing: Water Pub, 2010.

[12] Li, Xiaoqin. "On questions and countermeasures in phonetic teaching of college English" in Journal of Shandong Women's University, vol.2, 2011, pp: 86-88.

[13] Wang, Guizhen. English Pronunciation and Intonation for Communication. Beijing: Higher Education Press, 2010.

[14] Ning, Mi. "A study of the influence of English song teaching on college students' English learning interest" in Scientific Research, vol. 5, 2012, pp: 496-499.

[15] Zhao, Yang. "Analysis on professional English teaching” in Journal of Hubei TV University, vol.10, 2008, pp: 141-142. 